\title{
Deviant Behaviors of Students: Let's Try to Decrypt the Messages
}

\author{
Faten Hamdi ${ }^{1}$, Wissam Ben Khalifa ${ }^{1}$, Nabil Bakkari ${ }^{1}$, Mehrzia Zouaoui ${ }^{1}$ \& Ali Elloumi ${ }^{2}$ \\ ${ }^{1}$ High Institute of Sports and Physical Education of Kef, Tunisia \\ ${ }^{2}$ University Paris Descartes, France \\ Correspondence: Wissam Ben Khalifa, High Institute of Sports and Physical Education of Kef, Tunisia.
}

Received: March 21, 2018

doi:10.20849/aes.v3i3.462
Accepted: August 26, 2018

Online Published: September 7, 2018

URL: https://doi.org/10.20849/aes.v3i3.462

\begin{abstract}
Both teachers of physical education or other disciplines are distraught by the deviant behavior of their students. In order to detect and study these behaviors as well as teachers' reactions, we opted for a case study based research of five students adopting different deviant behaviors.

In fact, when conducting the case study of the five students, we were able to show how some of them suffered from the humiliation and belittlement of their teachers. Among the complex causes of challenging behaviors, there is the peculiar psychological history of each student. These behaviors are messages sent to adults (teachers), calls for help that we must not ignore, sanction them yes, but do not neglect them, it is better to take them seriously and seek to understand them and detect their causes in order to remedy it.

When students adopt deviant behaviors, the main challenge for the teacher is to remain able to perceive behind these adolescent students, humans in the making and continue to accompany them anyway. The multiplication of these deviant behaviors raises the question of the answers or professional reactions to face them. The dilemma of any teacher is to manage school deregulation situations so that there is no impact on the learning process.

The management of teacher-student conflicts is an essential element in order to guarantee that the latter does not break with the school institution.
\end{abstract}

Keywords: absenteeism, aggressiveness, teacher-student conflict, humiliation

\section{Introduction}

In the school context, some students may present themselves as elements that disrupt the classroom or that exhibit behavior that does not meet established standards. In addition, it is "the repetition of unacceptable behavior that disturbs the teacher and hinders learning" (Blin \& Gallais-Deulofeu, 2004, p9).

Many students present unacceptable behavior at some point in their school career, which makes them difficult to adapt. The deviant behaviors of students have been frequently studied in the field of education, described as "bad behavior" (Cothran \& Kulinna, 2007, Desbiens et al., 2008, Stephens, Kyriacou, \& Tønnessen, 2005), "unruly behavior" (Murcia, Gimeno, \& Galindo, 2007), "disruptive behaviors" (Desbiens \& al., 2008), or "disciplinary incidents" (Trottin \& Cogérino, 2009).

In addition, the educational reality of the classroom is a dynamic process in which the teacher appears to be the center. It is the result of his practice and his interaction with his students. Education involves a complex set of learning experiences that are planned and organized in a systematic, deliberate and interrelated way to bring about lasting change in a person's behavior. It focuses on school learning and aims at the same time the full development of the student (Morissette \& Gingras, 1989).

From here, we can say that the complexity of the teaching profession is not reduced to a set of technical skills whose mastery would ensure performance. Perrenoud (1992), following Freud, compares the teaching profession to an impossible profession because of the limits linked to the singularity of social actors and because failure, error, doubt and ambiguity constitute the intervention. There is no insured port. At the professional level, reflective practice is presented as the answer to this complexity. According to the same author, "this perspective implies, at the personal level, specific know-how: Analyze uncertainties and contradictions; manage blockages, disappointments, conflicts; anticipate the strategies of others and their consequences; negotiate compromises, reflect advantages and disadvantages." (Perrenoud, 1992, p85). 
For its part, the teacher, disturbed by the dilemma that forces him to choose between settling the conflict as an aside and continuing the lesson with the other students, sometimes engages in punitive actions to put an end quickly to this uncomfortable situation (Flavier \& Méard, 2003). Nevertheless, it should be noted that some teachers are reluctant to this practice by confusion between punishment and sanction.

\section{Methods}

In order to identify and explain the deviant behavior of students during physical education sessions and the reactions that their teachers may adopt, we opted for the case study of five students whose deviant behavior varies between verbal aggression, physical aggression and absenteeism.

In fact, our interview with our various subjects was mainly based on the reminders because we asked each of them to explain the reason for his deviant behavior, and eventually had to encourage them to keep talking. In the different case studies, we chose the initials of the first and last names of our students in addition to their ages in order to keep and especially respect their anonymity.

\section{Case Study \# 1: MB16}

\subsection{Presentation}

MB16 is sixteen; he comes from a wealthy family of five members: Parents plus one girl and two boys (including our student). MB16 is the eldest and favorite of his parents especially his mother who always defends and spoils him more than his brother and sister.

Regarding school guidance, MB16 chose the Technical section, something he later regretted by realizing that he should have chosen the experimental sciences section. Regretting his choice of school guidance and especially going since he no longer has the right to a reorientation, MB16 has "plunged" into absenteeism especially during the sessions of technology and mathematics.

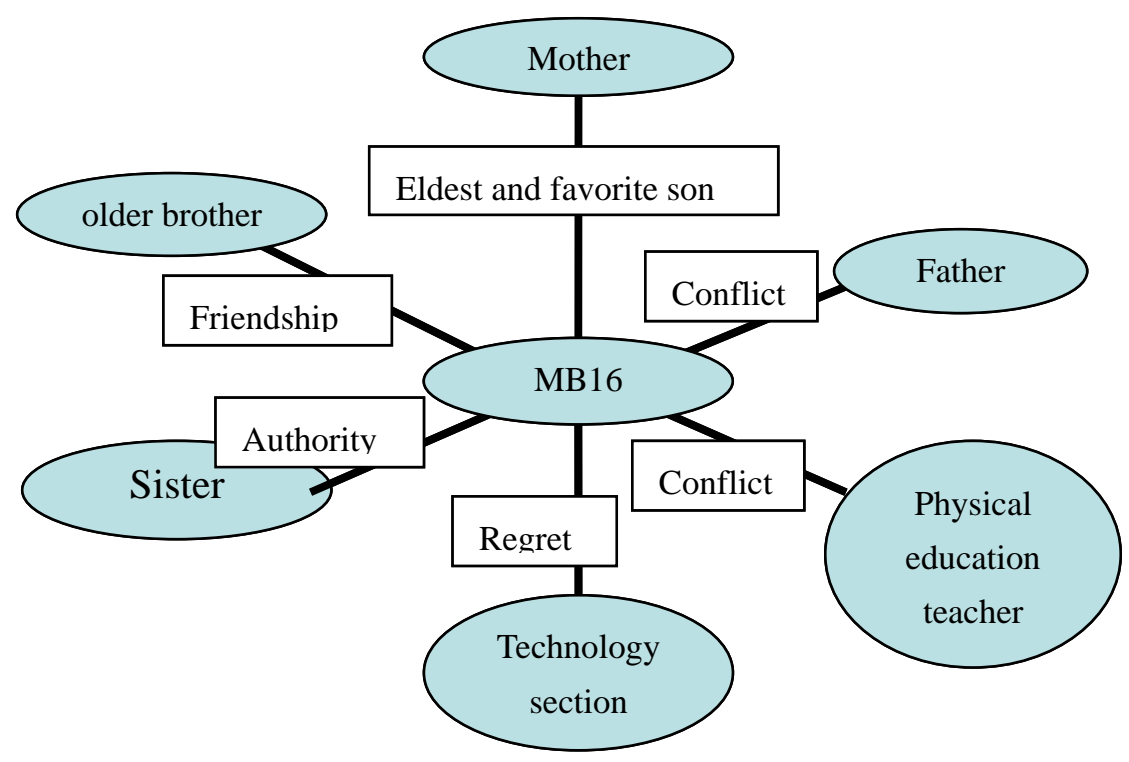

Figure 1. Case presentation \# 1 (MB16)

\subsection{Interview With MB16}

During the interview with MB16, our student explained the circumstances of his behavior towards his physical education teacher.

In fact, MB16 was absent (as usual) during the mathematics session, which is followed by the physical education session, and when he wanted to check whether he was missing or not, he went to the school athletics field where his class was with the physical education teacher, towards which he headed and this dialogue took place between him and his teacher: 
- "Hello, can I see the register?"

- "But what, who are you first?"

- "I belong to this class and I need to see if I am marked absent".

- "Stand up strictly."

- "I'm standing up, give me the call register".

- "No, I will not give you the call register".

- "I told you I really need the call register".

And there, the teacher stood up to walk away from our student while ignoring him and MB16 followed her and forcibly took her by her arm saying "Ey ma'am the call register, I need it". At that moment, the teacher got scared and turned to his colleague who was in another field and who came running and sent another student to get the supervisor.

\subsection{Interview With the Physical Education Teacher}

First of all, remember that our teacher is a novice and this is her first year of recruitment.

Referring to the incident with MB16, the physical education teacher told us that first of all "this student is absent a lot". She also added that she was surprised and scared when our student began to change his tone by asking for the call register as if he was threatening her and she started screaming, so she panicked and the first reaction she thought about was trying to "scare" MB16 which according to her becomes more and more aggressive.

\subsection{Analysis}

First, remind that MB16 is a student who missed his school orientation and who found himself in a section he does not like, hence the loss of any desire to attend classes that have lost all meaning for him such as mathematics or technology.

Actually, school guidance plays a decisive role in the students' future and is thus a great concern for them and is defined as "the whole of the psychological, psycho-social and social processes that make the young people in school are assigned to some training streams rather than others. When these courses are not very differentiated and their main objectives concern mainly general education, school guidance is quite distinct from vocational guidance. [...] If the subjects emit many choices of orientation, the institution that validates them makes a selection that can be more or less severe. Since the school population is divided into sectors of unequal value as to the benefits that can be expected from their attendance, orientation processes can be described as selection processes" (Guichard \& Huteau, 2007, p107).

As this definition confirms, the success of school guidance allows the student to make the right choice and "find his way" and "take charge" of the direction of his life (Guichard \& Huteau, 2005), unlike our student who missed his choice.

In addition, MB16 revealed to us that he lives this "painful situation", the fact of missing his orientation, he was alone without being supported by his family because he did not dare to speak to his father as he apprehends much his reaction especially that the latter is "hard" and "incomprehensible" and that he risks punishing him instead of supporting him.

Let's also add that our student is still a teenager (period of crisis and multiple conflicts), he always tries to "preserve" his image in front of his classmates. Being humiliated in front of them increases the chances of adopting aggressive behavior against his teacher, whom he judges to be "guilty" of the conflict between them because, according to him, she is "the culprit" since she shouted at him in front of the whole class.

We may even add that in some cases aggression (related to the stage of adolescence) can be justified and described as a defensive attitude as confirmed by Bouslimi \& Pineau (2001) that the defense mechanisms are still very rudimentary or archaic and present regressive behaviors manifested by excessive behaviors: bulimia, anorexia nervosa, aggressiveness and neurotic or psychotic states.

\subsection{Synthesis and Perspective}

As Guichard \& Huteau (2005) confirms, "orientation" refers to all the activities and reflexive processes of an individual allowing him to engage in a vocational training or career path and, more generally to "find one's way" and "take control" of the direction of one's existence ".

Unfortunately, for some students, such as the MB17 case, school guidance can cause twists and feelings of too late and chaos throughout their teaching career. Thus, Richoz (2010) p106 postulates "A well-known example of 
this institutional violence towards certain students concerns the mechanisms of orientation in certain pathways of study, which put the students under enormous pressure and generate for some a considerable suffering [...] The great misfortune is that this awareness of the issues does not give them the means to meet them. Those who fail to do so, often for reasons beyond their mere control, find themselves in an untenable situation as a human being, helpless in the face of an announced failure"

\subsection{New Track}

The pupil, his family, the teaching staff, the guidance workers must favor this choice because the orientation is not self-evident and is not limited to seeking information on a training or occupation. This is a process of building a course.

It is important to focus on dialogue with students in order to detect the causes behind their deviations. If a physical education teacher teaches a high school class in the first year of secondary school, it is better to ask students if they are satisfied with their school orientation so that they can help those who are not satisfied with their choices to the point of living even a discomfort that can influence their behavior.

It is better not to "give up" the students in their search for the choice of school guidance in order to facilitate their adaptation to school life, so we must try to guide them towards the teaching most in line with their abilities and to contribute to the development of their personality and to help them choose their path.

\section{Case Study \# 2: MG16}

\subsection{Presentation}

MG16 is from a wealthy family of 3 girls (including MG16), a boy and parents. At the age of 8, MG16 had to leave his family to live with his grandparents at the request of his mother. On the one hand, MG16 is jealous of his sister because the latter is the favorite of his father, but on the other hand she remains jealous of his brother because he is the favorite of his mother, in addition he is authoritarian with her. MG16 is repetitive in her class and she has learning difficulties in two subjects, French and English.

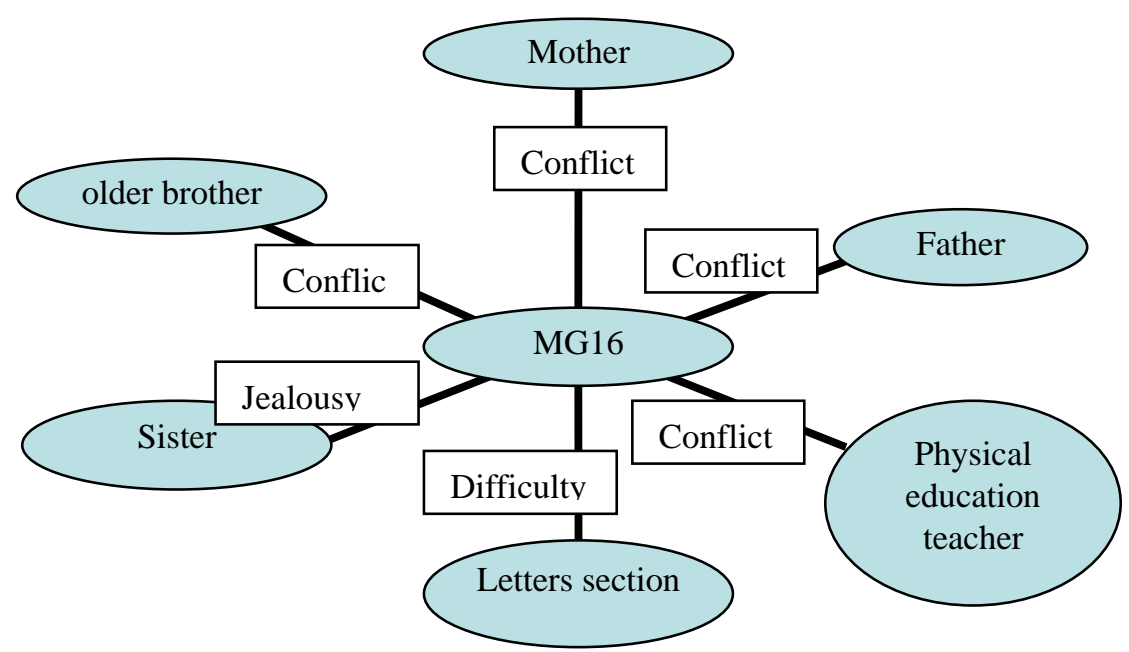

Figure 2. Case presentation \# 2 (MG16)

\subsection{Interview With MG16}

MG16 was standing in the queue behind her classmates waiting for her turn at the long jump session. In fact, she was chatting with her friend behind her when the teacher whistled her indicating the departure, at that moment she glanced at the jumper and she saw that the sand was not put back in place, without realizing (as our student pointed out) she shouted saying "Ey sir, but put the sand back in place". At that moment, the teacher, being surprised at the way his student spoke to him, replied "But why are you shouting at me, I am not an employee 
under your orders, I miss you respect" then MG16 became angry by adding "But I did not say anything, it is you who does not take care of the jumper and in addition you cry to me, it's my right, I cannot jump without the sand being put back in place.

"Oh," exclaimed the teacher, "all that and you did not say anything, I do not work under your orders and it's not you who will teach me how to do my job, besides you are impolite, you leave the session, you are excluded ".

MG16 left the session crying and the teacher started to write a report in order to give him an administrative penalty but when leaving high school he found our student still crying, so he resumed the discussion with her.

\subsection{Interview With the Physical Education Teacher}

The teacher told us the incident as MG16 did. In addition, the teacher added that the real reason that made him angry is that he was shouted at his students and that he considers this situation humiliating and that he believes he must react in "being firm "and sanction MG16 if not the other students will reproduce this transgression and he will lose any" power of authority "over them.

\subsection{Analysis}

MG16 is a teenager who had to move to live with her grandparents who live alone, and as a result, she moved away from her family and especially from her father. Her grandparents are hearing-impaired, which keeps her talking to them aloud and even shouting to communicate with them. Thus, MG16 has become accustomed to speaking aloud, even with other people.

In addition, the school failure that MG16 suffered has strongly marked her life; she often saw it as a fatality or a drama (Covington, Teel, \& Aussanaire, 2000).

In fact, school failure is defined as "regular practice of the school organization and its agents, practice in accordance with more or less codified procedures, underpinned by standards of excellence and institutionally defined levels of requirement. (Perrenoud, 1992, p240) or as a situation where an educational objective is not achieved (Landsheere, 1992).

Moreover, Covington et al. (2000) argue that school failure leads to a lack of motivation on the part of the student who is confronted with it, such as the case of MG16, to the point of developing feelings of shame, sadness and embarrassment. These feelings have made our student aggressive in his reactions especially in the school environment that reminds him of his failure. In addition, the existing relationship between academic failure, demotivation and unruly behavior strongly explains the MG16 incident with his physical education teacher.

\subsection{Synthesis and Perspective}

At the beginning of the school year, the class can be split in two: on the one hand the repeaters and on the other, the novice students.

Generally, repeaters find it difficult to fit into the classroom. Dialogue can be the best remedy for the teacher to know the difficulties they face but also their personal difficulties that often alter their motivation and can even influence their behavior by making them aggressive in their responses or their reactions especially they feel humiliated. Sometimes, in the face of humiliation, as confirmed by Merle (2002), the student adopts violent reactions, of rage, to recover another way of honor.

\subsection{New Track}

Deviant behavior, incivility or even aggression, regardless of the transgression committed by the student, it is not enough to make the decision to sanction or not. To look for the causes behind this deviant behavior through communication, but it is also better for the teacher, at the beginning of each school year, to get to know his students better by doing his "small surveys" in order to know the repeaters in order to be aware of their situation. This situation is characterized by a mixture of demotivation and manifestation of indiscipline. As stated by Vianin (2007) that for a student, repeating or being oriented towards a specialized structure, it is to be placed on the sidelines, not to find a place in his own world, the school. While most teachers share a concern for the fight against secondary failure, many people often feel very lonely and helpless in this fight. In addition, classroom management is becoming more and more difficult for teachers: the school population is increasingly heterogeneous, parents have become critical, and researchers question the very functioning of the school. 


\section{Case Study \# 3: LR16}

\subsection{Presentation}

LR16 comes from a poor family with seven members: The parents, a half-sister, a half-brother, LR16, a sister and a brother.MR16 revealed to us that he is closer to his mother than his father with whom he has a conflictual relationship where the dialogue is absent (LR16 revealed to us that his father never took him in his arms). The father of LR16 is illiterate. The older sister of LR16 is married and he rarely sees her because her husband forbids her to see her family, for which he misses her a lot. The older brother of LR16 (who is closest) left the house to engage the military.

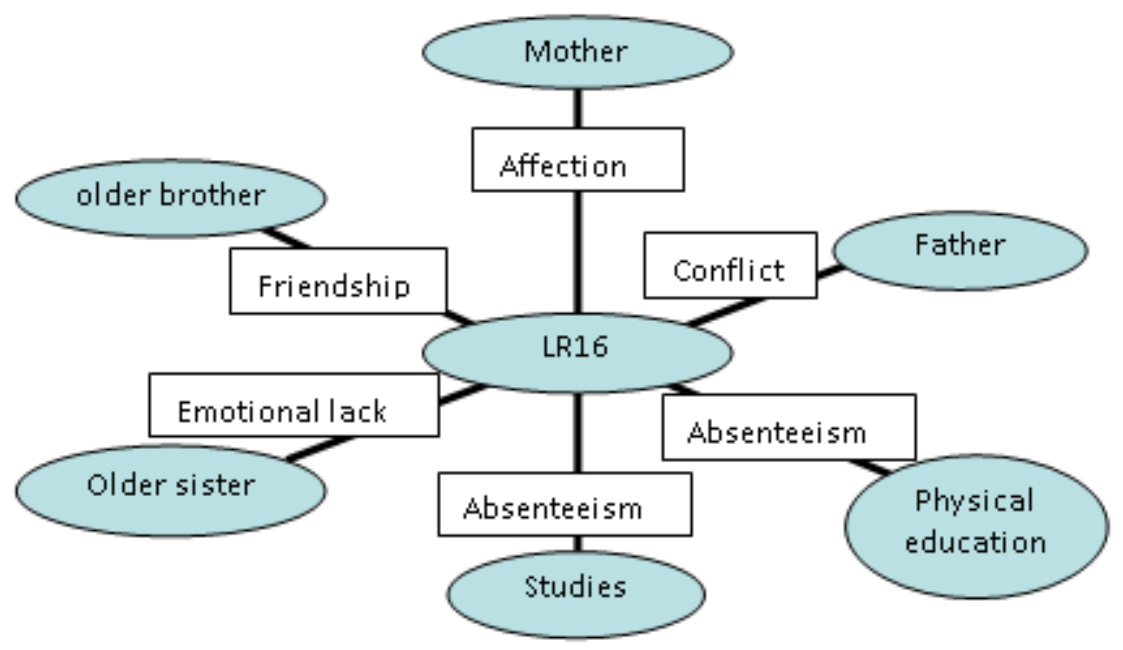

Figure 3. Case presentation \# 3 (LR16)

\subsection{Interview With LR16}

During the interview with LR16, the latter revealed to us that he started to be absent because he felt "lost", "sad", and "alone" for several reasons:

- Because of his conflictual relationship with his father that he considers "hard" and "incomprehensible". Moreover, since his school failure, his father has become more "severe" with him and he does not stop to describe him as "failed".

- Because of his school failure, LR16 became unmotivated and this towards all subjects.

- Despite his passion for judo, LR16 has even abandoned training because he wants to avoid meeting his classmates (social anxiety).

\subsection{Interview With the Physical Education Teacher}

According to his physical education teacher, LR16 is a good judoka. But, LR16 began to be absent from the beginning of the school year for all disciplines including physical education (general absenteeism).

Furthermore, our teacher told us that she tried to talk to LR16 twice to understand the cause of his absenteeism while trying to convince him to change his attitude: attending classes and preparing for exams for success but in vain.

In addition, the physical education teacher said that LR16 revealed to her that he had family problems and that he lost all desire to study.

\subsection{Analysis}

LR16 is a teenager (remember that adolescence is the age of extremism and paradoxes as the transition from a need of solitude, withdrawal, a need for sharing, communication with others or the passage of enthusiasm for indifference and apathy, or delicacy for rudeness and disrespect: of safety, self-confidence, worry and anxiety) who has lived school failure that has affected our student by making him "sad" and "permanently worried" which can even induce a school depression. As emphasized by Blanchard, Casagrande, \& McCulloch (1994) that in the most serious cases, this situation can be described as a school depression, i.e. a depression not of the individual 
as such but which is linked in a specific way to the school context. The student feels mortification and grieves about his integration into the school.

Moreover, Blin \& Gallais-Deulofeu (2004) confirm that a student who is failing in school is a student who can be passive and does not seek to correctly perform, understand or carry out the school tasks assigned to them. But our pupil chose to leave and escape this institution in which he had a painful experience and he was abandoned by his family who did not support him, on the contrary his father even punished him and continues to do so, besides he does not stop humiliating him.

\subsection{Synthesis and Perspective}

Absenteeism is synonymous with school refusal, especially if the student in question has already had a school failure. In fact, there are two forms of absenteeism: general absenteeism and disciplinary absenteeism. LR16 has plunged into widespread absenteeism and this attitude persists because no one has taken charge (no teacher) of the mission to contact his parents in order to collaborate with them to help LR16 to reinstate his high school and attend his classes.

\subsection{New Track}

Among the complex causes of challenging behaviors, there is the peculiar psychological history of each student. These behaviors are messages sent to adults (teachers), calls for help that we must not ignore, sanction them yes, but do not neglect them, it is better to take them seriously and seek to understand them and detect their causes in order to remedy it.

Whether it is generalized (to all disciplines) or regular (in a discipline), absenteeism is a deviant behavior that deserves teachers to take it seriously and think about intervention methods. It is true that an absent student does not disturb the course of the session, but it remains under the responsibility of the teacher who must intervene and even seek to involve parents to work together and understand the causes of this behavior.

\section{Case Study \# 4: ZR16}

\subsection{Presentation}

ZR16 is a judoka and he likes this discipline a lot. He comes from a wealthy family of five members: Parents, two sisters and two boys including ZR16. He is closer to his mother than to his father with whom he has a conflictual relationship where dialogue is almost absent. In addition, ZR16 is close to his sisters with whom he considers as confidants.

Once, ZR16 and his older brother quarrelled in high school, so his father forced him to change schools. For this reason, ZR16 resents his father. Thus, ZR16 began to adopt aggressive behavior in the new high school as a reaction to "the injustice of his father". He was even dismissed from high school for three days as a result of a report from the physical education teacher because of his incessant disruptive behavior.

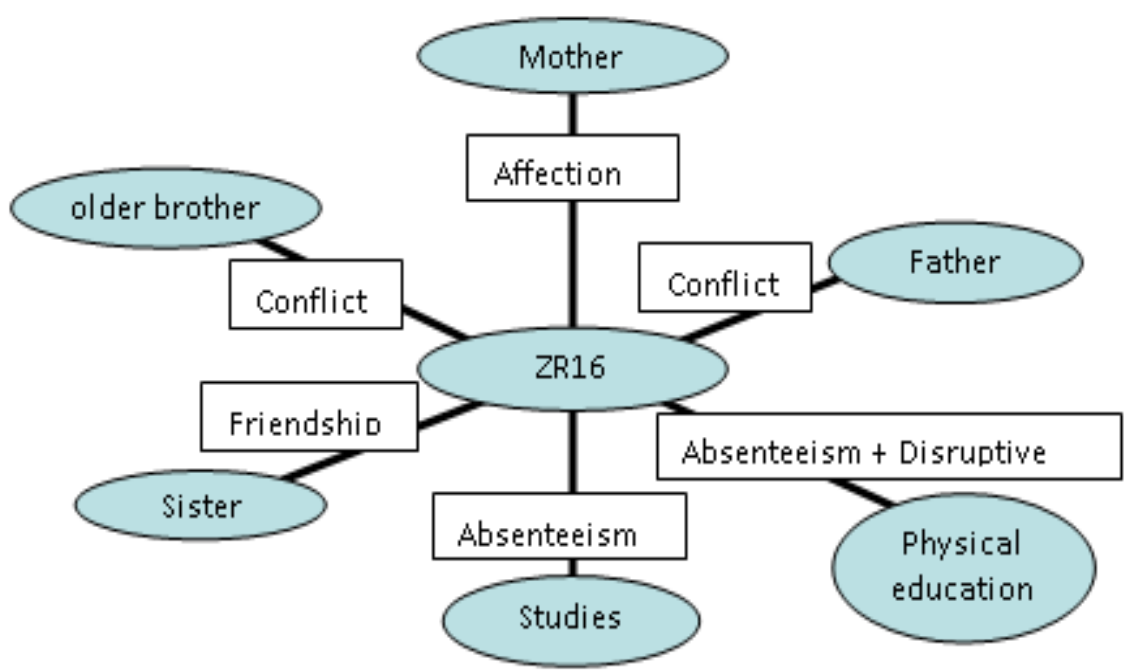

Figure 4. Case presentation \# 4 (ZR16) 


\subsection{Interview With ZR16}

During the interview with ZR16, our student revealed that he began to be absent and to engage in disruptive behaviors such as chatter and heckling when his father forced him to change high school. Thus, our student instead chose to adopt deviant behaviors to express "his rage" and his refusal for this decision that his father inflicted on him "just to satisfy his other spoiled son" as ZR16 said.

In addition, ZR16 revealed that by changing his high school, his father took him away from his classmates with whom he has established good relations for years.

And asking him to describe his relationship with his father, ZR16 said that "it's war".

\subsection{Interview With the Physical Education Teacher}

The physical education teacher said that ZR16 is a student who is "either absent or present and doing the clown". The teacher also added that ZR16 is a student who is not interested in the session and who is always trying to chat and shout behind her back.

On the other hand, the teacher did not seek to know the reason (s) for which this student adopts this behavior or if his absenteeism is widespread or disciplinary.

\subsection{Analysis}

ZR16 adopts two deviant behaviors: absenteeism and chatter. Indeed, these two behaviors are different, certainly, but are similar in the fact that they are both a manifestation of total indifference of the school institution. As confirmed by Blin \& Gallais-Deulofeu (2004) p199 "Having discipline problems does not mean being heckled anymore, just that you cannot get a sufficiently low noise level to be able to work. This chatter is not an expression of student hostility, but rather of their indifference. It's a latent form of absenteeism. The teacher plays a part to occupied spectators doing something else".

In this case, our student seeks to escape from this school institution that his father imposed on him. Without realizing that by changing him from his old high school, he moved him away from his classmates with whom he formed friendly relationships (remember the importance of peer relationships during adolescence as pointed out by Lehalle (1995).

This conflictual relationship experienced by ZR16 with his father can also be discussed through psychoanalysis. the latter insisted on the disinvestment of important emotional relationships as with parents and which can manifest itself through aggressive behavior that signifies revolt. In our case, the student revolts against his father's decision to "snatch" him from his old high school. Thus, claiming the nickname "disruptive pupil" or undisciplined is the revenge chosen by ZR16 against his father.

Note also that the father of ZR16 was not coveted in high school only after the report of the teacher of physical education when he could have been informed by the disruptive behavior of his son to try to collaborate together to help him overcome this painful situation.

\subsection{Synthesis and Perspective}

Transgressions of externalised students may be the expression of difficulties. Nevertheless, it must be pointed out that the sufferings and anxieties of adolescents can manifest themselves in less disruptive forms of daily school life and are emergency calls that can lead to tragedy if they are not taken seriously. Faced with these transgressions, the teacher can communicate with the student's parents without ever stopping to criticize but he must try to highlight the student progress.

\subsection{New Track}

Students are willing to invest in school work if they feel listened to, understood and recognized as a person accepted in their difficulties. Thus, teachers must make sure to establish interpersonal relationships. "Unconditionally accept students, is to accept that they do not fit the model we have of the "good student" who sends us a positive image and rewarding ourselves as a teacher. It is to accept that they escape our cultural and educational influence. It is not always to draw "bad student" the inventory of our disappointed expectations, but to accept them as they are, in order to help them to progress by starting from where they are and by relying on their strong points, by encouraging them, by complimenting them for the least of their achievement, even if it does not belong to the strictly academic field" (Peretti, Rohart, Maccio, Collectif, \&Avanzini, 2008, p48). 


\section{Case Study \# 5: CS16}

\subsection{Presentation}

SC16 is from a wealthy family of five members: The parents, two sisters and SC16.SC16 is the eldest of his family. He has a conflictual relationship with his older sister with whom he is constantly fighting. SC16 started smoking at 14 , but he stopped when he started weightlifting training. Thus, our student started to miss classes that start around 14:00 hours to go to the training sessions.

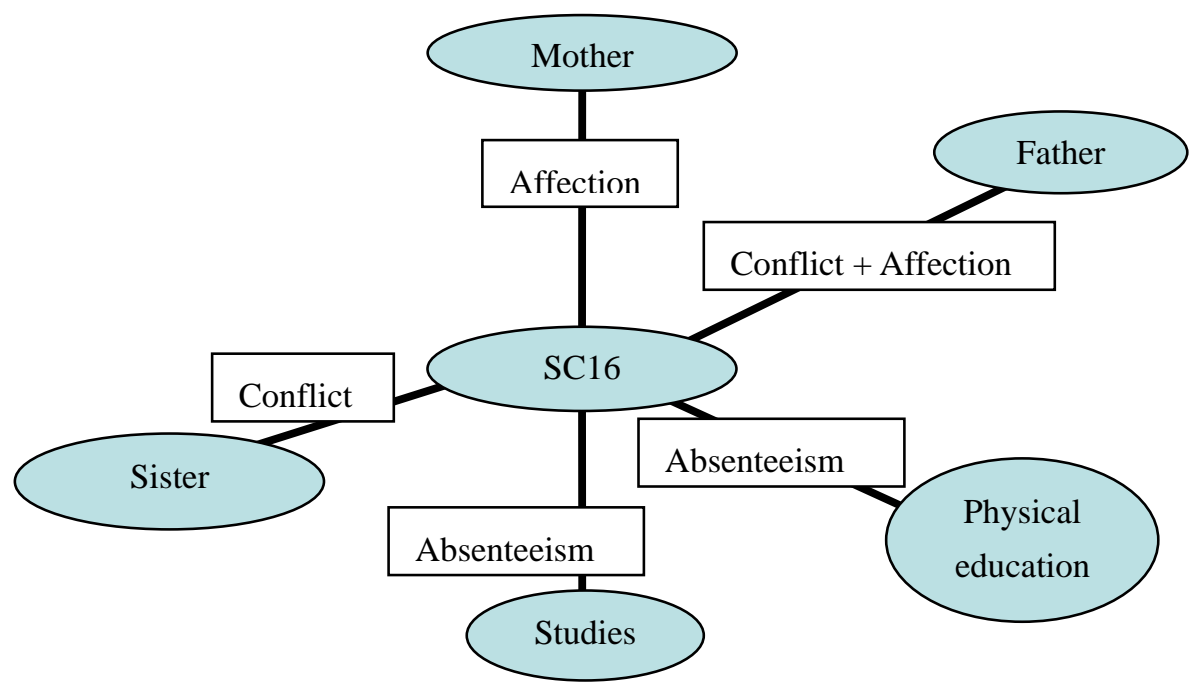

Figure 5. Case presentation \# 5 (SC16)

\subsection{Interview With CS16}

During the interview with SC16, he revealed to us that he is the favorite of his parents because they spoil him a lot and he gets everything he wants which made his older sister jealous. Because of this jealousy, SC16 is in conflict with his sister, who is always trying to criticize him and denounce him to his parents.

SC16 started smoking at 14 years to imitate his friends, "I found myself in a group of boys who smoke, so I did like them" said SC16.

About his absenteeism, SC16 said he began to be absent when he started weightlifting. The problem was that the training hours coincided with those of the course, and to choose, SC16 preferred not to miss the training because his body began to change and become "muscular and beautiful".

In addition, SC16 finds that his parents never punished or penalised him, even when they were made aware of his absenteeism, they just a little scolded him orally without taking any serious action. SC16 added that his mother was always at his disposal to take a back-to-school ticket.

In addition, SC16 has revealed that he is too attached to his computer found in his room and used "at will" and without any parental control.

\subsection{Interview With the Physical Education Teacher}

The SC16 physical education teacher revealed that the student is "polite", "disciplined", "wise" but "very absent". So, there was never any question of conflict between our two subjects and yet there is a deviant behavior or a transgression reported by our teacher: it is absenteeism.

Moreover, asking our teacher if SC16's absenteeism was widespread or disciplinary, she replied that she "had no idea".

\subsection{Analysis}

What is striking during the interview with the physical education teacher who "complained" about SC16's absenteeism is that she did not know, or did not try to know, whether this absenteeism is generalized or disciplinary in order to better understand her student's attitude. According to her, CS16 is a "disciplined" student at least during the sessions he attended. 
Regarding the causes or reasons why SC16 is absent from physical education sessions, we were able to deduce that our student, quite the contrary, "likes", as he explained, the physical activities and the proof is that he is registered in a weightlifting club and jogging daily, but he is indifferent to studies because they do not represent any significance for him: weightlifting has allowed him to have a body he desires, "and studies" (according to him), "what are they for?"

In this case, the student presents a general indifference to teaching. This is a proclaimed disinterest that induces passivity. In fact, SC16 is either weightlifting or he is in his room in front of his computer (the cyber dependence). This pace of life plus parental passivity (lack or absence of parental control) has made SC16 unable to get in project, to think rigorously about his future or to produce a prolonged intellectual effort (Richoz, 2010). The attitude of SC16's parents encouraged their son to seek only his interests. Concerning this parental attitude (Guillot, 2006) argues that non-directivity, misunderstood by many parents and teachers, will promote permissiveness, especially that of the child, to express any desire.

\subsection{Synthesis and Perspective}

We can conclude that the absenteeism of SC16 can be explained by an indifference to studies in general. This indifference can be explained by the lack of commitment (whether emotional, behavioral or cognitive) of our student in the learning process as highlighted by Fredricks, Blumenfeld, \& Paris (2004). In fact, absenteeism is a way that student uses to express indifference to classes or discomfort (e.g. family problems), that affects the behavior at the point of choosing to move away or even to flee the school.

\subsection{New Track}

Absenteeism may be the result of academic failure, lack of motivation, family problems or relational difficulties with the teacher. Absenteeism is also described as a form of passivity. To remedy this it is better that the teacher tries to find the causes of this deviant behavior while involving the parents to collaborate for the good of the student.

\section{General Discussion of Different Case Studies}

Through the various case studies, we find that the interviewed teachers did not really seek to discuss with their students in order to understand the causes or reasons for their transgressions. In addition, no teacher has focused on adolescence, the age range to which our students belong, and its possible influence on their behavior.

Faced with absenteeism, our teachers remain passive by simply mentioning it on the call register without trying to detect the sent message through this attitude: the adopted absenteeism by student is to escape only physical education classes or is it generalized? Or is it to escape the physical education teacher? Several causes are possible, to remedy this, we must begin to identify them.

\section{General Synthesis of Different Case Studies}

Studies have shown that a number of variables related to school such as academic achievement, school attitudes and learning-oriented school environments are related to less deviant behavior (Hirschfield \& Gasper, 2011; Hoffmann et al. 2013; Stewart, 2003) On the contrary, negative academic attitudes, conflicts between teachers and students, and poor academic outcomes predict more deviant behavior (Rudasill et al 2010; Wang, Brinkworth \& Eccles 2013). School links are based on similar positive interactions between students and school staff (e.g., teacher-student) and thus facilitate learning of prosocial and normative behaviors (Hoffmann and Dufur 2008).

The management of teacher-student conflicts is an essential element in order to guarantee that the latter does not break with the school institution. Thus, the teacher must not resign in front of disinterested or disruptive students or said "difficult" especially when they are teenagers. As stipulated by Marcelli (2003) p146 "The contemporary adolescent is above all a being of paradoxes. He wants to be completely autonomous, but at the same time he asks his parents for banal acts of everyday life. It states absolute, intangible truths; at the same time he deeply doubts himself, his body, others. Even as his thought opens to the categories of the possible and to the infinite field of hypotheses, his body is irremediably transformed into a rigorously defined sex. He is often extraordinarily altruistic at the same time as he can reveal fantastically selfish. He never ceases to call himself deeply individualistic and at the same time he melts into a band or a way that makes it difficult for him to discern from his peers. [...] However he feels these contradictions: we could say that adolescence is precisely this period that the individual experiences of the contradictions, the paradox and the suffering they cause."

By approaching adolescence, we must not forget the positive side as the boundless energy of youth and their desire to undertake several projects and new interests. Also, physical education is a fundamental discipline in elementary school. It brings so much to the child construction at all points of view: motor, cognitive, relational and social. Numerous are the developed skills in physical education course, whether they are specific to this 
discipline or general and transversal. Moreover, it is also a remarkable means to fight against school failure and it carries fundamental values (Boutigny \& Guériot, 1998).

Physical education and sport is a discipline that can be interesting and meaningful for all students if teachers are able to maintain good relationships with them.

In addition, the teacher-student relationship should be less based on arbitrary authority, but more on greater understanding while avoiding humiliation and belittlement.

The school institution should not be thought of as merely a place of knowledge transmission or a background of performance worship, but as a better space for socialization.

Various studies have focused more specifically on analyzing this phenomenon in the context of physical education classes (Brunelle, 1995). Physical activity would have beneficial effects in reducing risk behaviors, especially among adolescents.

Following the case study of our five students (in particular MG16 and LR16) we can say that humiliation is present in the teacher-student relationship while being a subjective experience and quite painful for the latter. The humiliation was felt several times by our students who lived as a belittlement.

In fact, humiliation is a kind of public stigmatization of the student's mistakes as highlighted (Merle, 2002); it is also a public questioning, and a "sort of symbolic killing of his pupil status in front of his comrades". In physical education class, humiliation can be exercised when a pupil does not succeed in a sporting skill and his teacher asks him to do it again in front of his classmates, or when he makes him understand in public that he has had a bad note or when he shouts at him.

Sometimes teachers adopt devaluing practices that can be painful experiences for students and may even lead them to seek exemption from physical education sessions, as in the MB16 student's case.

\section{Conclusion}

The evils of adolescent students are so multiple that they can sometimes express them but by adopting deviant behaviors such as: absenteeism, aggression, etc. Each of the five interviewed students had a variety of "pain" to externalize like MB16 who missed his school orientation or LR16 who suffered from the authoritarianism of his father. Many students are in great psychological distress due to family problems, stressful events or simply problematic developments in society and that their condition prevents them from behaving normally while expressing their suffering at school, in the hope that it will be perceived by the teachers. This accumulation of tensions leads to an emotional escalation that can be exploded in various forms of incivility and violence. So, we can say that students' deviant behaviors are not usually directed at teachers, but rather are inappropriate messages that hide requests for help and listening.

\section{Acknowledgments}

The authors express their deepest thanks to teachers and students for their effort to accomplish this study.

\section{References}

Blanchard, F., Casagrande, E., \& McCulloch, P. (1994). Échec scolaire: nouvelles perspectives systémiques. ESF.

Blin, J.F., \& Gallais-Deulofeu, C. (2004). Classes difficiles : Des outils pour prévenir et gérer les perturbations scolaires. Paris: Delagrave.

Bouslimi, J., \& Pineau, J.C. (2001). Adolescentes, adolescents en pratiques sportives. L'Harmattan.

Boutigny, C.A., \& Guériot, P. (1998). L'éducation physique à l'école. Paris: Magnard.

Brunelle, J.P. (1995). Prévenir et gérer l'indiscipline dans l'enseignement de l'éducation physique: une approche pédagogique pour opérationnaliser l'intervention en éducation physique qui vise le développement de la personne. GRIAP, Département d'éducation physique, Université Laval.

Cothran, D.J., \&Kulinna, P.H. (2007). Students' reports of misbehavior in physical education. Research Quarterly for Exercise and Sport, 78(3), 216-224. https://doi.org/10.1080/02701367.2007.10599419

Covington, M.V., Teel, K.M., \& Aussanaire, M. (2000). Vaincre l'échec scolaire: Changer les raisons d'apprendre. De Boeck Supérieur.

Desbiens, J.F., Lanoue, S., Spallanzani, C., Tourigny, J.S., Turcotte, S., Roy, M., \& Brunelle, J.P. (2008). Une analyse des comportements perturbateurs survenus durant des cours d'éducation physique et à la santé enseignés par des stagiaires. Staps, 81(3), 73-88. https://doi.org/10.3917/sta.081.0073

Flavier, E., \& Méard, J.A. (2003). Comprendre les conflits professeur-élève(s) en EPS. EPS, 303, 25-28. 
Fredricks, J.A., Blumenfeld, P.C., \& Paris, A.H. (2004). School Engagement: Potential of the Concept, State of the Evidence. Review of Educational Research, 74(1), 59-109. https://doi.org/10.3102/00346543074001059

Guichard, J., \& Huteau, M. (2005). L'orientation scolaire et professionnelle. Paris: Dunod (Col. Topos).

Guichard, J., \& Huteau, M. (2007). Lexique de l'orientation et de l'insertion professionnelle en soixante-seize notions. Paris: Dunod (Col. Topos).

Guillot, G. (2006). L'autorité en éducation: sortir de la crise. ESF Ed.

Hirschfield, P.J., \& Gasper, J. (2011). The relationship between school engagement and delinquency in late childhood and early adolescence. Journal of Youth and Adolescence, 40(1), 3-22. https://doi.org/10.1007/s10964-010-9579-5

Hoffmann, J.P., \& Dufur, M.J. (2008). Family and school capital effects on delinquency: Substitutes or complements?. Sociological Perspectives, 51(1), 29-62. https://doi.org/10.1525/sop.2008.51.1.29

Hoffmann, J.P., Erickson, L.D., \& Spence, K.R. (2013). Modeling the association between academic achievement and delinquency: An application of interactional theory. Criminology, 51(3), 629-660. https://doi.org/10.1111/1745-9125.12014

Landsheere, G.de. (1992). Dictionnaire de l'évaluation et de la recherche en éducation (2nd éd. rev. Etaugm.). Presses Universitaires de France-PUF.

Lehalle, H. (1995). Psychologie des adolescents (4th ed.). Paris: Presses Universitaires de France-PUF.

Marcelli, D. (2003). L'Enfant, chef de la famille : L'autorité de l'infantile (Albin Michel.). Paris: Albin Michel.

Merle, P. (2002). L'humiliation des élèves dans l'institution scolaire : contribution à une sociologie des relations maître-élèves. Revue Française De Pédagogie, 139(1), 31-51. https://doi.org/10.3406/rfp.2002.2880

Morissette, D., \& Gingras, M. (1989). Enseigner des attitudes? planifier, intervenir, évaluer. Québec/Paris: De Boeck-Wesmael/Les Presses de l'Université Laval.

Murcia, J., Gimeno, E., \& Galindo, C. (2007). Perception of Discipline According to Gender, Type of School, Sport Activity and Interest in Physical Education in Spanish Students. International Journal of Applied Sports Sciences, 19(2), 35-49.

Peretti, A.de, Rohart, J.D., Maccio, C., Collectif, \& Avanzini, G. (2008). Carl Rogers et l'action éducative. Chronique Social.

Perrenoud, P. (1992). La triple fabrication de l'échec scolaire. In Pierrehumbert, B., L'échec à l'école : échec de l'école (pp. 85-102). Paris: Delachaux et Niestlé.

Richoz, J. (2010). Gestion de classes et d'élèves difficiles. Lausanne: FAVRE.

Rudasill, K.M., Reio, T.G., Stipanovic, N., \& Taylor, J.E. (2010). A longitudinal study of student-teacher relationship quality, difficult temperament, and risky behavior from childhood to early adolescence. Journal of School Psychology, 48(5), 389-412. https://doi.org/10.1016/j.jsp.2010.05.001

Stephens, P., Kyriacou, C., \& Tønnessen, F.E. (2005). Student Teachers' Views of Pupil Misbehaviour in Classrooms: A Norwegian and an English setting compared. Scandinavian Journal of Educational Research, 49(2), 203-217. https://doi.org/10.1080/00313830500049004

Stewart, E.A. (2003). School social bonds, school climate, and school misbehavior: A multilevel analysis. Justice Quarterly, 20(3), 575-604. https://doi.org/10.1080/07418820300095621

Trottin, B., \& Cogérino, G. (2009). Filles et garçons en EPS: approche descriptive des interactions verbales entre enseignant-e et élèves. Staps, 83(1), 69-85. https://doi.org/10.3917/sta.083.0069

Vianin, P. (2007). La motivation scolaire: Comment susciter le désir d'apprendre. De Boeck Supérieur. https://doi.org/10.3917/dbu.viani.2007.01

Wang, M.T., Brinkworth, M., \& Eccles, J. (2013). Moderating effects of teacher-student relationship in adolescent trajectories of emotional and behavioral adjustment. Developmental Psychology, 49(4), 690. https://doi.org/10.1037/a0027916

\section{Copyrights}

Copyright for this article is retained by the author(s), with first publication rights granted to the journal.

This is an open-access article distributed under the terms and conditions of the Creative Commons Attribution license (http://creativecommons.org/licenses/by/4.0/). 